\title{
Legitimate Expectation of Consistent Interpretation of EU State Aid Law: Recovery in State Aid Cases Involving Advanced Pricing Agreements on Tax
} DOI:

10.1093/jeclap/lpx028

\section{Document Version}

Accepted author manuscript

Link to publication record in Manchester Research Explorer

Citation for published version (APA):

Lovdahl Gormsen, L., \& Mifsud-Bonnici, C. (2017). Legitimate Expectation of Consistent Interpretation of EU State Aid Law: Recovery in State Aid Cases Involving Advanced Pricing Agreements on Tax. Journal of European Competition Law \& Practice, 8(6), 1-14. https://doi.org/10.1093/jeclap/lpx028

Published in:

Journal of European Competition Law \& Practice

\section{Citing this paper}

Please note that where the full-text provided on Manchester Research Explorer is the Author Accepted Manuscript or Proof version this may differ from the final Published version. If citing, it is advised that you check and use the publisher's definitive version.

\section{General rights}

Copyright and moral rights for the publications made accessible in the Research Explorer are retained by the authors and/or other copyright owners and it is a condition of accessing publications that users recognise and abide by the legal requirements associated with these rights.

\section{Takedown policy}

If you believe that this document breaches copyright please refer to the University of Manchester's Takedown Procedures [http://man.ac.uk/04Y6Bo] or contact uml.scholarlycommunications@manchester.ac.uk providing relevant details, so we can investigate your claim.

\section{OPEN ACCESS}




\section{Legitimate Expectation of Consistent Interpretation of EU State aid Law: Recovery in State aid cases involving advanced pricing agreements on tax}

Liza Lovdahl Gormsen and Clement Mifsud-Bonnici ${ }^{1}$

- This paper examines whether the recovery obligations in the recent tax cases are acceptable in the light of the general principles of EU law on legal certainty, legitimate expectations and proportionality.

- It argues that the Commission's order of recovery in the tax cases is highly questionable.

- The Commission's expansive interpretation of State aid prohibition was not foreseeable and its retrospective recovery of the State aid is arbitrary and goes against the principle of legal certainty.

- It concludes that in the Commission could have used other means of dealing with advanced pricing agreements on tax to provide clarity and respect the principle of proportionality.

\section{Introduction}

The EU State aid rules are under the world's spotlight with the European Commission's (the 'Commission') recent decision that Ireland has to recover up to $€ 13 \mathrm{bn}$ plus interest from Apple. The Commission alleges that "Apple only paid an effective corporate tax rate that declined from 1\% in 2003 to $0.005 \%$ in 2014 on the profits of Apple Sales International." " What matters is what Apple ultimately pays in tax on a global basis, including U.S. repatriation taxes, rather than what its international subsidiaries pay in one or another jurisdiction. However, the Commission appears to be less interested in the rules governing taxation of global multinational companies, and rather more interested in gaining some political capital. Prior to the Apple decision, the Commission has issued decisions against Starbucks $^{3}$ and Fiat ${ }^{4}$ ordering Luxembourg and the Netherlands to recover illegal aid (the 'tax cases'). Other companies such as Amazon, McDonald's and GDF Suez's tax arrangements are currently being scrutinized..$^{5}$

\footnotetext{
${ }^{1}$ L.L.G. is a senior research fellow at the British Institute of International and Comparative Law, the Director for the Competition Law Forum, and a senior lecturer in Law at the University of Manchester. C.M.B is an advocate admitted to the Malta Bar and an associate at GANADO Advocates (Malta). The research carried out for this article has not been funded by any corporation or funding body. The authors are grateful to BIICL research assistant Alsarif Satti, who has provided research assistance on this article. We would also like to thank the following people for helpful comments and suggestions: Conor Quigley QC (Barrister at Serle Court); Dominic Robertson (Tax Partner at Slaughter \& May); Dimitrios Kyriazis (University of Oxford) and Dr Melanie Smith (Associate Professor University of Cardiff). The analysis and conclusions expressed herein are solely those of the authors, and responsibility for any mistakes remain ours alone.

${ }^{2}$ Commission Decision of 30 August 2016 State aid SA.38373- (Apple). European Commission, press release no. IP/16/2923 of 30 August 2016.

${ }^{3}$ Commission Decision of 21 October 2015 on State aid SA.38374- (Starbucks).

${ }^{4}$ Commission Decision of 21 October 2015 on State aid SA. 38375-(Fiat).

${ }^{5}$ State aid SA.38944 - (Amazon); State aid SA. 38945 - (McDonald's) and SA.44888 - (GDF Suez).
} 
This paper argues the Commission's order of recovery in the recent tax cases is highly questionable due to the Commission's novel legal analysis of EU State aid law. ${ }^{6}$ While the Commission is in its good right to change the way in which it thinks about State aid, it has to change its thinking in a manner that is foreseeable. Otherwise it runs counter to the general EU law principle on legal certainty and breaches the legitimate expectations of multinational companies, which make use of tax rulings issued by national tax authorities to manage their tax liability efficiently. The very objective of an advance pricing arrangement ('APAs') is the achievement of legal certainty to a multinational's tax liability. While multinationals cannot entertain legitimate expectations merely on the basis that such an arrangement was concluded with a national tax authority, these widely used practices give an important context to this paper. The EU bloc, as a whole, attempts to attract and stimulate investment, thus it is important that multinationals have legal certainty. It is a general principle of EU law, which is shared by the national legal orders of all EU Member States, and one which puts investors at ease that their rights and property are protected. Therefore, within the context of the widespread use of tax rulings and also the significant amount of tax liability shouldered by multinationals, a defence of legitimate expectations should not be discounted hastily.

We are not challenging the use of State aid rules in the area of tax, ${ }^{7}$ as long as the Commission does not overstretch the scope of the State aid prohibition in its pursuit to achieve EU tax legislation. Neither are we arguing that legal certainty means keeping things status quo. Rather it is argued that the Commission's novel interpretation of selectivity was not foreseeable and its retrospective recovery of the State aid is arbitrary and goes against the principle of legal certainty. While legal certainty means a lot of different things to great many people, to us legal certainty exists to prevent a public authority like the Commission - from acting in an arbitrary manner. It may have been foreseeable that the Commission was going to curb harmful tax competition - a valuable public concern - but not that it was going to intervene in national tax rulings to such an extent that it effectively sets itself up as a further court of appeal in all tax matters. Under EU law direct taxation remains a sole national issue outside the Commission's competence.

The Commission is likely to see the recent judgment of the Court of Justice of the European Union (the 'CJEU') in Banco Santander and Autogrill (now World Duty Free Group SA) ${ }^{8}$ as an endorsement of its approach to tax cases as the court rejected the traditional three-stage test in assessing tax State aid.

\footnotetext{
${ }^{6}$ Liza Lovdahl Gormsen, 'EU State Aid Law and Transfer Pricing: A Critical Introduction to a New Saga' (2016) 7(6) JECLAP 369. For a detailed account see also Dimitrios A Kyriazis, 'From Soft Law to Soft Law Through Hard Law: The Commission's Approach to the State Aid Assessment of Tax Rulings' (2016) 15(3) EStAL 428 and Conor Quigley QC, 'Tax Rulings and State Aid' (2016) Tax Journal 8.

${ }^{7}$ Case C-173/73 Italy v Commission (2 July 1974) ECLI:EU:C:1974:71.

8 Joined Cases C-20/15P and C-21/15 P Commission v World Duty Free Group ECLI:EU:C:2016:981.
} 
However, this is the first time the court has rejected the traditional approach and thus could not have been foreseeable for national tax authorities issuing tax rulings in the 1990s and 2000s. This is even more so given the disagreement about the tax rulings within the Commission. While Commissioner Vestager has argued that tax rulings "are by nature selective", 9 the Commission's view is that "[t]ax rulings as such are perfectly legal." 10

The paper's overall conclusion is that the Commission should have not ordered recovery of aid in the tax cases, as it is arbitrary and runs against three key EU law principles: protection of legitimate expectations, legal certainty (clarity and precision and non-retroactivity) and proportionality. Multinational companies were entitled to rely on the interpretation and application of EU State aid law as known to them at the time of granting of aid. If the Commission decides to adopt a distinct interpretation of Article $107 \mathrm{TFEU}$, without allowing companies a reasonably transitional period to adjust their tax affairs, it should not order recovery of that aid. While recovery is a mechanism, which attempts to restore the situation before the granting of aid, ${ }^{11}$ and is not equivalent to imposing a fine for anticompetitive behaviour, it may also be punitive in nature if the recovery runs well above the multimillion euro mark, goes back up to 10 years and more importantly is applied retroactively. The Commission should have engaged with its Member States, their tax and accounting bodies and multinational groups affected by its change in State aid analysis to afford those affected the opportunity to amend their arrangements with national tax authorities. It could also have proposed to the Council a new regulation on the basis of Article 109 TFEU.

\section{Non-recovery of State Aid and General Principles of EU Law}

Neither Articles 107 nor 108 TFEU expressively provide that unlawful aid has to be recovered from the beneficiaries. The Commission's power to order recovery was established by the CJEU. ${ }^{12}$ Arguably, the recovery of aid is the logical consequence of a finding that aid is incompatible with the internal market and follows from the use of the word 'abolish' in Article 108 (2) TFEU. ${ }^{13}$ Some initial jurisprudence referred to 'illegal aid' rather than 'incompatible aid', thus implying that mere failure to notify State aid triggers the obligation on the Member State to recover. However, case law has clarified

\footnotetext{
9 'Tax avoidance and privacy in the digital age' (Transatlantic Citizens' dialog in New York/Milan, 21 September 2016) at 24:30 minutes $<\mathrm{http}: / /$ ec.europa.eu/citizens-dialogues/italy/milano2/index_en.htm>.

${ }^{10}$ See IP/16/2923 (n 2).

${ }^{11}$ Case C-142/87 Belgium v Commission ECLI:EU:C:1990:125, para 66; Joined Cases C-278/92, C-279/92 and C-280/92 Spain v Commission ECLI:EU:C:1994:325, para 75; Case C-350/93 Commission v Italy ECLI:EU:C:1995:96, para 21; Case C-310/99 Italy $v$ Commission ECLI:EU:C:2002:143, para 98.

${ }^{12}$ Case C-70/72 Commission v Germany ECLI:EU:C:1973:87 (Kohlegesetz case).

${ }^{13}$ Kohlegesetz case (n 13), para 13; Case C-310/85 Deufil v Commission ECLI:EU:C:1987:96, para 24; Case C-142/87

Belgium v Commission ECLI:EU:C:1990:125, para 66; Case C-310/99 Italy v Commission ECLI:EU:C:2002:143, para 98.
} 
that lack of notification of aid does not give the Commission power to recover aid. The Commission must find that the aid is incompatible with the internal market before ordering recovery. ${ }^{14}$ The CJEU has recognised the following possible defences to counter an order of recovery: legal certainty (limitation period), transfer of economic activity and the protection of legitimate expectations.

The focus of this paper however is principally on those which fall within the umbrella of 'general principles of EU law'. ${ }^{15}$ According to the Procedural Regulation in 1999 (amended in 2015), ${ }^{16}$ the Commission shall not require recovery of the aid if this would be contrary to a general principle of Union law. This is interpreted to include, the principle of legal certainty and the principle of protection of legitimate expectations. ${ }^{17}$

Article 6(3) TEU ascertains that the general principles are to be located at the same level as the Treaties of the EU. The principles are therefore deemed to have "constitutional status". ${ }^{18}$ The principle of legal certainty gains even more weight as a sub-principle of the rule of law, which is enshrined in Article 2 TEU as a core value of the EU. Article 6(3) TEU links the general principles of EU law not only to Member States' constitutional traditions but also to individuals' rights. Legal certainty is therefore more than a mere guiding principle for the legislature.

\section{A. The Principle of Legal Certainty}

Legal certainty is a fundamental principle of $\mathrm{EU} \mathrm{law}^{19}$ and part of the general overarching principles of EU law. ${ }^{20}$ The CJEU developed the notion of general principles emanating from national constitutions in order to avoid conflicts with national provisions that Member States deemed indispensable. ${ }^{21}$ That way, the court reconciled the primacy of EU law with the protection of fundamental rights in the EU. ${ }^{22}$

\footnotetext{
${ }^{14}$ Case C-301/87 France v Commission (14 February 1990) ECLI:EU:C:1990:67 (Boussac case). This does not stop, however, an interested party from seeking recovery of 'illegal aid' (therefore which has not been notified) before the national courts of the relevant Member State in the interim.

${ }^{15}$ This was recognised more generally in Case 223/85 RSV v Commission ECLI:EU:C:1987:502 (hereafter 'RSV v Commission'), para 17.

${ }^{16}$ Council Regulation (EC) 659/1999 laying down detailed rules for the application of Article 93 of the EC Treaty [1999] OJ L083/1, Article 14 as amended by Council Regulation (EU) 2015/1589 laying down detailed rules for the application of Article 108 of the Treaty on the Functioning of the European Union (codification) [2015] OJ L248/9, Article 16(1).

${ }^{17}$ Bucura Catalina Mihaescu, 'Recovery of Unaidful Aid and the Role of the National Courts' in Herwig C H Hofmann and Claire Micheau (eds), State Aid Law of the European Union (OUP 2016) 389.

${ }^{18}$ Jérémie Van Meerbeeck, 'The Principle of Legal Certainty in the Case-Law of the European Court of Justice: from Certainty to Trust' (2016) 41(2) European Law Review 275, 280.

${ }^{19}$ Joined Cases 42 and 49/59 S.N.U.P.A.T. v High Authority ECLI:EU:C:1961:5 [1961] ECR 0101.

${ }^{20}$ Case 11/70 Internationale Handelsgesellschaft mbH ECLI:EU:C:1970:114.

${ }^{21}$ Paul Craig, UK, EU and Global Administrative Law: Foundations and Challenges (CUP 2015) 334, 337.

${ }^{22}$ Damian Chalmers, Gareth Davies and Giorgio Monti, European Union Law: Cases and Materials (3 ${ }^{\text {rd }}$ edn, CUP 2014) 252.
} 
Moreover, the principle of legal certainty is a fundamental element of the rule of law. It essentially seeks to ensure that laws are foreseeable, "clear, precise and predictable as regards their effects". ${ }^{23}$ In 2011, the Venice Commission of the Council of Europe identified legal certainty as one of the six necessary elements that comprise the rule of law, and therefore, legal norms must be clear and applied in a foreseeable and consistent manner. ${ }^{24}$ Subjects of the law must be able to know its precise content, so as to plan their conduct accordingly. ${ }^{25}$ The CJEU has confirmed this understanding in Plantanol: ${ }^{26}$

The principle of legal certainty, the corollary of which is the principle of the protection of legitimate expectations, requires, on the one hand, that rules of law must be clear and precise and, on the other, that their application must be foreseeable by those subject to them.'

The CJEU has repeatedly held legal rules must be clear and precise in their application, otherwise the foreseeability of situations and legal relationships governed by EU law is doubted. ${ }^{27}$ However, the normative content of legal certainty is not exhausted with this general aphorism. In Heinrich, the CJEU held that: ${ }^{28}$

'[t]he principle of legal certainly requires that Community rules enable those concerned to know precisely the extent of the obligations which are imposed on them. Individuals must be able to ascertain unequivocally what their rights and obligations are and take steps accordingly.'

The principle of legal certainty is not merely addressed to legislative bodies, but also to administrative authorities when issuing administrative orders. ${ }^{29}$ The scrutiny required by the principle increases where the violation of a law leads to sanctions. ${ }^{30}$ As regards the principle of clarity and definiteness, the CJEU even established a rule of interpretation stating that vague laws shall be interpreted in favour of the addressee. ${ }^{31} \mathrm{An}$ interesting implication of the principle arises where multiple sources of law apply. EU law, even when disregarding Member State law, is a complex, multi-layered body of law with a heavy influence of quasi-legislative activity by the CJEU. Under these circumstances situations may arise

\footnotetext{
${ }^{23}$ Joined Cases C-72/10 and C-77/10 Marcello Costa et alia [2012] ECLI:EU:C:2012:80, para 74.

${ }^{24}$ European Commission for Democracy through Law (Venice Commission), 'Report on the Rule of Law' (Adopted by the Venice Commission at its 86th Plenary Session, Venice 25-26 March 2011), paras 41-51

$<$ www.venice.coe.int/webforms/documents/?pdf=CDL-AD(2011)003rev-e >.

${ }^{25}$ Takis Tridimas, The General Principles of EU Law (OUP 2006) 242.

${ }^{26}$ Case C-201/08 Plantanol, para 46 (citations omitted, emphasis added).

${ }^{27}$ Case C-94/05 Emsland-Stärke ECLI:EU:C:2006:185 [2006] ECR I-2619, para 43; Case C-199/03 Ireland v Commission ECLI:EU:C:2005:548 [2005] ECR I-8027, para 69; Case C-29/08 SKF ECLI:EU:C:2009:665 [2009] ECR I-10413, para 77. ${ }^{28}$ Case C-345/06 Heinrich ECLI:EU:C:2009:140 [2009] ECR I-1659, para 44 (citations omitted). See also Case C-143/93 Gebroeders van Es Douane Agenten BV v Inspecteur der Invoerrechten en Accijnzen ECLI:EU:C:1996:45 [1996] ECR I431, para 27; Case C-161/06 Skoma-Lux ECLI:EU:C:2007:773 [2007] ECR I-10841, para 38.

${ }^{29}$ Case T-43/02 Jungbunzlauer AG v Commission ECLI:EU:T:2006:270 [2006] ECR II-3435, para 72.

${ }^{30}$ Stefanie Schmahl, '§ 6 Rechtsstaatlichkeit' in R Schulze, M Zuleeg and S Kadelbach (eds) Europarecht (3rd edn, Nomos, 2015) 299.

${ }^{31}$ Tridimas (n 25) 244 in reference to Case 169/80 Administration des Douanes v Gondrand Frères [1981] ECR 1931, para 17 et seq.
} 
where individuals find themselves unable to determine the applicable law. In such a situation the principle of clarity and definiteness may be violated. This is even more so in the area of direct taxation, where the Commission has no competence.

In the realm of State aid control, the principle of legal certainty usually comes into play in regards to the issue of the limitation period. ${ }^{32}$ However, a fundamental element of the principle of legal certainty is a presumption against the validity of the retroactive application of legal norms. ${ }^{33}$ As a general rule, retroactivity cannot be reconciled with the requirements of the principle of legal certainty and by extension with the rule of law. This applies not only in criminal law, but also in administrative law, insomuch as the retroactive application of a legal rule would negatively affect rights and legal interests of the subject of the law. The EU courts have developed a very interesting jurisprudence on the matter, the departure point of which is that the principle of legal certainty precludes a rule from being applied retroactively. ${ }^{34}$ Therefore, it cannot be excluded that the principle of legal certainty might advocate against the retroactive application of State aid law in a particular case, insomuch as the Commission endorses a novel interpretation of State aid.

\section{B. The Principle of the Protection of Legitimate Expectations}

The principle of legitimate expectations encompasses all situations where legal subjects reasonably rely on the persistence of a legal situation influenced by EU institutions. While one might see a strong connection to the principle of non-retroactivity, ${ }^{35}$ the practice of the EU courts seem to put more emphasis on whether or not individuals reasonably relied on circumstances influenced by EU law. ${ }^{36} \mathrm{~A}$ literal interpretation of this notion may lead to the misconception that laws, policies and individual acts cannot be changed due to the reliance of some individual. ${ }^{37}$ Simple logic and legislative, as well as administrative, efficiency demand that this cannot be the case. That is why, according to EU case law, legitimate expectations may only arise where the legal situation caused expectations on which the addressee relied, the reliance was reasonable and the individual interest preponderates conflicting public interests (principle of proportionality) ${ }^{38}$ These three conditions are now analysed in turn.

\footnotetext{
${ }^{32}$ See Case T-308/00 Salzgitter v Commission ECLI:EU:T:2004:199 [2004] ECR II-1933 and Case C-408/04 P Commission v Salzgitter ECLI:EU:C:2008:236 [2008] ECR I-2767.

${ }^{33}$ Chalmers, Davies and Monti (n 22) 441.

${ }^{34}$ Case 98/78 Racke ECLI:EU:C:1979:14 [1979] ECR-0069, para 15; Case 99/78 Decker ECLI:EU:C:1979:15 [1979] ECR 0101, para 3; See Pablo Martín Rodríguez, 'A Missing Piece of European Emergency Law: Legal Certainty and Individuals' Expectations in the EU Response to the Crisis' (2016) 12(2) European Constitutional Law Review 265, 266.

${ }^{35}$ See Paul Craig, EU Administrative Law (2nd edn, OUP 2012) 553.

${ }^{36}$ Case C-24/95 Land Rheinland-Pfalz v Alcan Deutschland ECLI:EU:C:1997:163 [1997] ECR I-1591, para 34 et seq.

${ }^{37}$ Also pointing at this conflict Craig (n 35) 555.

${ }^{38}$ Alcan Deutschland (n 36), para 34 et seq; Schmahl (n 30) 300.
} 


\section{B.1. Expectations on which the Addressee Relied}

The principle of legitimate expectations - as a principle of EU law as well as civil law principle - is acknowledged in cases of individual decisions of administrative authorities; that is the revocation or annulment of lawful and unlawful administrative acts. ${ }^{39}$ It is, however, also generally accepted that even informal representations can be the source of legitimate expectations. ${ }^{40}$ When it comes to laws and general policies - instruments that are not addressed to a specific individual - the general rule of EU law states that individuals cannot invoke the principle of legitimate expectations on the basis that the prevailing legal situation shall remain unchanged. Regulatory and administrative bodies have a margin of discretion within which they can alter policies. ${ }^{41}$ Legitimate expectations may only arise in specific situations of individual bargains or assurances by EU institutions. ${ }^{42}$

\section{B.2. Reasonable Reliance and Proportionality}

While EU law knows a variety of situations from which legitimate expectations may arise, not every reliance of individuals is protected under the principle. The General Court stressed in Opel Austria that the principle of legitimate expectations has an inherent connection to the principle of good faith. ${ }^{43}$ Only those who act in good faith can rely on the principle. Individuals are not in good faith where a change in policy was "foreseeable". ${ }^{44}$ To assess foreseeability the courts investigate whether a "prudent and well-informed" 45 market participant could have foreseen the changes made by EU institutions.

Reasonable reliance on the continuity of policies alone does not lead to the protection of individual interests under the principle of legitimate expectations. In fact, legitimate expectations may only arise where there are no precluding public interests. To assess whether public interests override individual expectations both positions are weighed in a proportionality test. ${ }^{46}$ The courts will attach more weight to individual interests where individual representations have been made and will generally let public interests prevail where EU bodies chose to change general policies. ${ }^{47}$ Thus, when the Commission

\footnotetext{
39 Juha Raitio, The Principle of Legal Certainty in EC Law (Kluwer Academic Publishers 2003) 200 and $214 \mathrm{ff}$.

40 ibid 200; Schmahl (n 30) 300 et seq; Craig (n 35) 553, 567 et seq.

${ }^{41}$ Case 52/81 Offene Handelsgesellschaft in Firma Werner Faust v Commission ECLI:EU:C:1982:369 [1982] ECR 3745 , para 26 et seq.

${ }^{42}$ Craig (n 35) 575.

${ }^{43}$ Case T-115/94 Opel Austria GmbH v Council ECLI:EU:T:1997:3 [1997] ECR II-39, para 93.

${ }^{44}$ Tridimas (n 25) 265; Schmahl (n 30) 301.

${ }^{45}$ Case C-350/88 Société Française des Biscuits Delacre et alia v Commission ECLI:EU:C:1990:71 [1990] ECR I-395, para 37.

${ }^{46}$ Craig (n 35) 586 et seq.

47 ibid 586; Schmahl (n 30) 301.
} 
decides to change the way in which it applies the State aid rule to tax arrangements, it ought to give affected parties - in these tax cases the national tax authorities and the multinational companies - a reasonable transitional period to adjust their affairs. This is what national tax authorities are obliged to do, as confirmed in GSTS Pathology v Revenue \& Customs. ${ }^{48}$

The principle of proportionality may also require transitional provisions to make sure that individual rights are not violated. ${ }^{49}$ The order for recovery is, in principle, restorative and not punitive in nature. The jurisprudence of the CJEU holds, on the same line of reasoning, that 'recovery for the purpose of re-establishing the previously existing situation cannot, in principle, be regarded as disproportionate to the objectives of the Treaty provisions on State aid ${ }^{50}$ However, the CJEU does admit that there might be exceptions to this rule, and therefore, each case must be assessed individually.

\section{B.3. Legitimate Expectations as a Defence against Recovery}

The protection of legitimate expectations has always been a difficult defence to run. The CJEU designed the parameters for invoking this defence in Commission v Germany, namely, that aid must have been granted in compliance with the procedure in Article 108 TFEU and that the beneficiary could have been able to determine whether that procedure was followed if a diligent businessman would have. ${ }^{51}$ The court did add, however, that this defence may only succeed in 'exceptional circumstances' ${ }^{52}$ This test is now settled case law. ${ }^{53}$ In practice, this requires: firstly, that the aid is notified to the Commission in terms of Article 108(3) TFEU and also that the aid is not granted before the procedure is exhausted; and secondly, that only specific circumstances of an exceptional character can be relied on by the beneficiary. The latter requirement requires a case by case assessment.

This needs to be applied concurrently with the general rules of application of the principle of legitimate expectations in EU administrative law. ${ }^{54}$ It is required that the individual is in a situation in which it is clear that the EU institution has, by giving him precise assurances, led him to entertain reasonable

\footnotetext{
${ }^{48}$ GSTS Pathology LLP, R (on the application of) v Revenue \& Customs [2013] EWHC 1823 (Admin).

${ }^{49}$ Craig (n 35) 555.

${ }^{50}$ Examples are Case C-148/04 Unicredito Italiano SpA ECLI:EU:C:2005:774, para 113; Case C-372/97 Italy v Commission ECLI:EU:C:2004:234, para 103.

${ }^{51}$ Case C-5/89 Commission v Germany ECLI:EU:C:1990:320, para 14. The origins of this test can be traced back to Case C74/74 CNTA ECLI:EU:C:1975:59 and Case C-78/77 Firma Johann Lührs v Hauptzollamt Hamburg-Jonas

ECLI:EU:C:1978:20, which introduced the concept of a prudent and discriminating trader as the objective standard to make this assessment.

${ }^{52}$ Commission $v$ Germany (n 51), para 16.

${ }^{53}$ Case C-183/91 Commission v Greece ECLI:EU:C:1993:233, para 18; Case C-169/95 Spain v Commission

ECLI:EU:C:1997:10, para 5; Alcan Deutschland (n 36), para 25; Case T-288/97 Regioneautonoma Friuli-Venezia Giulia v Commission ECLI:EU:T:2001:115, para 107.

${ }^{54}$ Case C-84/78 Angelo Tomadini ECLI:EU:C:1979:129, para 20; Case C-112/80 Dürbeck ECLI:EU:C:1981:94, para 48. See also M Dougan, National Remedies before the Court of Justice (Hart 2004) 351.
} 
expectation, but these assurances must be precise, unconditional and contain consistent information. ${ }^{55}$ The manner in which the assurance is given to the party entertaining legitimate expectations is irrelevant, so long as the requirements laid down by CJEU jurisprudence are met. ${ }^{56}$ Commentators agree that there are broader categories of 'precise assurances' on the basis of past administrative decisional practice and CJEU jurisprudence. ${ }^{57}$

In the field of State aid law, the sometimes nebulous concept of what is effectively 'aid' is crucial when applying the test laid out in Commission v Germany. If a measure does not qualify as 'aid' within the meaning of Article 107(1) TFEU, the notification obligation flowing from Article 108(3) TFEU and the relevant provisions in the Procedural Regulation is not triggered. Novel interpretations of the notion of aid in particular, pose a significant threat to the legitimate expectations of any potential beneficiary within the internal market. Similarly, in complex transactions State aid elements may be 'invisible or at least very difficult to detect' ${ }^{58}$ In antitrust cases for example where a novel issue is being considered, the courts have been inclined to reduce the fine being imposed. ${ }^{59}$ In AKZO Chemie BV v Commission the CJEU considered that the novelty of the abuse warranted a reduction in the fine imposed. ${ }^{60}$ While an antitrust fine is different from recovery of unpaid tax, there is an analogy to be made in terms of legitimate expectations, which will be discussed in more detail below. The key difficulty is the interpretation of the notion of aid upon which the beneficiary may rely.

This paper argues that the concept of 'precise assurance' has been interpreted widely in certain circumstances and this warrants that a beneficiary may, in 'exceptional circumstances', entertain legitimate expectations on the basis that the Commission adopts a novel interpretation and application of EU State aid law, in particular, since this may have prejudicial retroactive effects on the beneficiary.

\section{CJEU Jurisprudence and Past Decisions of the Commission: A Case of Two Weights, Two Measures?}

There are two key fora before which the defence of legitimate expectations is examined: before the Commission (prior to an order for recovery) and subsequently before the national courts of Member

\footnotetext{
${ }^{55}$ Case T-66/96 and T-221/97 Mellett ECLI:EU:T:1998:187, para 104; Case C-537/08 P Kahla Thüringen Porzellan GmbH ECLI:EU:C:2010:769, para 64; Case T332/06 Alcoa ECLI:EU:T:2009:79, para 102.

56 ibid.

${ }^{57}$ Krzysztof Jaros and Nicolai Ritter, 'Pleading Legitimate Expectations in the Procedure for the Recovery of State Aid: What are the Recent Developments in Case Law and the Commission's Practice' (2004) 4 EStAL 573, 579; Adrien Giraud, 'A Study of the Notion of Legitimate Expectations in State Aid Recovery Proceedings: "Abandon all hope, ye who enter here"?' (2008) 45 CMLR 1399, 1413-1418; Conor Quigley, European State Aid Law and Policy (Hart Publishing 2015) 583-584.

58 Jaros and Ritter (n 57) 578.

${ }^{59}$ Giorgio Monti, 'Recovery Orders in State aid Proceedings: Lessons from Antitrust?' (2011) 10 EStAL 415.

${ }^{60}$ Case C-62/86 ECLI:EU:C:1991:286, para 163.
} 
States (when enforcing an order for recovery issued by the Commission, but also potentially in a claim by a private interested party). The examination of the Commission may, within certain limitations, also be subject to further review before the General Court and the CJEU in case of an action for annulment against a decision delivered by the Commission.

The availability of this defence in national courts and before the CJEU increases the possibility of discrepancy in interpretation and application of the test developed by Commission v Germany. There is a gap in practice where a beneficiary, which has not challenged a Commission decision in terms of Article 263 TFEU, raises the defence of legitimate expectations before the national courts. ${ }^{61}$ Jaros and Ritter argue that there exists a tension between the principle of administrative finality of the Commission decision and the need to afford protection of the legitimate expectations of the beneficiary. The proposed way forward is for national courts to apply the test developed in Commission v Germany and consider exceptional circumstances only where they were not made known to the Commission during the investigation procedure since the beneficiary could not rely on that evidence at that stage (if it had an active role to play in any case). The fact that the defence of legitimate expectations can be raised both before national courts and the CJEU has also given rise to a discrepancy in the level of protection of legitimate expectations of beneficiaries present under the relevant national laws generally against that applicable within the context of State aid. ${ }^{62}$

According to jurisprudence, the defence of legitimate expectations cannot be upheld solely on the basis of an act of a Member State, but can only be entertained by precise assurances by 'Community administration' ${ }^{63}$ However, administrative practice and jurisprudence expose poor consistency in what constitutes a 'precise assurance'. ${ }^{64}$ The latter was expanded to include reliance on past Commission decisions ${ }^{65}$ or even CJEU judgments, ${ }^{66}$ which do not concern the beneficiary or its situation directly.

\footnotetext{
${ }^{61}$ Jaros and Ritter (n 57) 574-575.

${ }^{62}$ Alcan Deutschland (n 36).

${ }^{63}$ See Case C-213/06 P EAR v Karatzoglou ECLI:EU:C:2007:453, para 33 and the case law cited.

${ }^{64}$ See literature (n 57).

${ }^{65}$ Commission Decision 2003/438/EC of 16 October 2002 on the aid scheme for finance companies implemented by Luxembourg [2003] OJ L153/40, Recitals 63; Commission Decision 2003/501/EC of 16 October 2002 on the State aid scheme for coordination centres implemented by Luxembourg [2003] OJ L170/20, Recitals 68; Commission Decision 2003/883/EC of 11 December 2002 concerning State aid scheme C 46/2001 for central corporate treasuries (Centrales de trésorerie) implemented by France [2003] OJ L330/23, Recitals 44; Commission Decision 2003/515/EC of 17 February 2003on the State aid implemented by the Netherlands for international financing activities [2003] OJ L180/52, Recitals 111; Commission Decision 2003/601/EC of 17 February 2003on aid scheme by Ireland for foreign income [2003] OJ L204/51, Recitals 56; Commission Decision 2004/77/EC of 24 June 2003on the aid scheme implemented by Belgium for tax ruling system for United States foreign sales corporations [2004] OJ L23/14, Recitals 77.

${ }^{66}$ Commission Decision 2005/565/EC on an aid scheme implemented by Austria for a refund from the energy taxes on natural gas and electricity in 2002 and 2003 [2005] OJ L190/13, Recitals 62-66.
} 
In a number of State aid cases, ${ }^{67}$ the Commission did not order the recovery of the aid due to the legitimate expectations of the parties to the decisions. In those cases as well as other cases,${ }^{68}$ the authority was based on a decision delivered on 2 May 1984 regarding tax relief for coordinated services of multinational companies - a scheme introduced by a Belgian Royal Decree. ${ }^{69}$ The decision was never published in the Official Journal, but was referred to in the XIV ${ }^{\text {th }}$ Report on Competition Policy and in an Annex citing State aid cases ${ }^{70}$ and in an answer to a Parliamentary question. ${ }^{71}$ The Commission has relied on the decision delivered on 2 May 1984 in many decisions later on specifically to conclude that the beneficiaries under the scheme in those cases had a legitimate expectation that the aid would not be recovered. ${ }^{72}$ The Commission relied on the 1984 decision as a 'precise assurance' in a number of State aid cases decided between 2002 and 2006. This is a crucial precedent which should not be discounted either by the Commission or by alleged beneficiaries in more recent cases. ${ }^{73}$

The Commission gave a brief account of the 2001 wave of investigations in its 2007 'State Aid Scoreboard' Report. ${ }^{74}$ The Commission reiterates therein that, by means of the 1984 decision, the Belgian scheme for coordination centres was initially found not to involve State aid. The Commission decided to deviate from this long-established approach only in 2001 and pursuant to a political initiative of the Council to counter harmful tax competition. Since, however, the Commission had not raised objections when it examined the initial Belgian scheme, it held that this decision created legitimate expectations not only for the Belgian authorities, but for a number of other Member States that had implemented similar schemes in the meanwhile. ${ }^{75}$

This line of Commission decisions relying on an 'assurance' in the form of a past Commission decision - a positive act. However, the Commission is, in principle, prepared to accept that novel interpretations of State aid could give rise to legitimate expectations under EU law without the need for an assurance, in whatever form. The Commission held that France Télécom was entitled to entertain legitimate

\footnotetext{
${ }^{67}$ See decisions (n 65).

${ }^{68}$ We have identified more cases which did the same: Commission Decision 2003/81/EC of 22 August 2002 on the aid scheme implemented by Spain in favour of coordination centres in Vizcaya [2003] OJ L31/26, Recital 44; Commission Decision 2003/512/EC of 5 September 2002 on the aid scheme implemented by Germany for control and coordination centres [2003] OJ L177/17, Recital 43; Commission Decision 2003/755/EC of 17 February 2003 on the aid scheme implemented by Belgium for coordination centres established in Belgium [2003] OJ L282/25, Recital 122; Commission Decision 2004/76/EC of 13 May 2003 on the aid scheme implemented by France for headquarters and logistics centres [2004] OJ L23/1, Recital 81.

${ }^{69}$ Royal Decree No 187 of 30 December 1982 on the taxation of coordination centres.

${ }^{70}$ Commission XIV th $R$ eport on Competition Policy (1985) 237.

${ }^{71}$ Answer given by Sir Leon Brittan on behalf of the Commission (Written question no 1735/90 by Mr Gijs de Vries to the Commission of the European Communities) [1991] OJ C63/37.

${ }_{72}$ Cases (n 27). Heinrich (n 28). See also Skoma-Lux (n 28), para 38.

${ }^{73}$ In Commission Decision 2011/5/EC on the tax amortisation of financial goodwill for foreign shareholding acquisitions implemented by Spain, however, the Commission held that the 1984 decision could not be relied upon by Spain, in order to invoke the existence of legitimate expectations, as the measure at issue did not concern intra-group activities.

${ }^{74}$ Commission, 'State Aid Scoreboard: spring 2007 update' COM(2007) 347 final 21-22.

${ }^{75}$ ECOFIN Conclusion 1 December 1997 concerning taxation policy (98/C 2/01).
} 
expectations that oral declarations which were not per se legally binding could not fall within the scope of Article 107(1) TFEU: ${ }^{76}$

'(263) The Commission recognises that this is the first time it has had to examine whether this type of conduct constitutes aid. In so far as the aid depends, as a result, on conduct which preceded the notification of the shareholder loan proposal, a diligent operator could have had confidence in the lawfulness of the conduct of the Member State concerned, which, for its part, had duly notified the loan proposal. As AG Darmon stated in his Opinion in Case C-5/89, 'the doubts with which some undertakings may be assailed, when faced with "atypical" forms of aid, as to whether notification is necessary should not be made light of'.

(264) In conclusion, the Commission finds that France Télécom could legitimately have confidence in France's conduct not constituting state aid. In the light of the above, the Commission considers that, in the present case, ordering the aid's recovery would be contrary to the general principles of Community law.'

AG Darmon specifically raised the point that a beneficiary may be at odds whether conduct should be notified. Arguably, this point relates to the subject-matter being considered in this paper, for there is a discrepancy on the interpretation of the arm's length principle, which raises doubts as to whether it is (notifiable) aid..$^{77}$

\section{Fiat, Starbucks and Apple: Legal Certainty and a Legitimate Expectation of Consistent Interpretation of the Law}

The Commission ordered recovery of aid in Starbucks, Fiat and Apple. It is unknown whether the Commission will do the same in Amazon, McDonald's and GDF Suez. The main premise of this paper is that the Commission's interpretation of Article 107(1) TFEU in these cases is novel and unprecedented, and thus, there should be no recovery.

In Fiat, Luxembourg argued that the Commission infringed the principle of legitimate expectations on the basis that it departed from agreements reached in the Code of Conduct Group and the OECD Forum on Harmful Tax Practices. ${ }^{78}$ The Commission discounted the argument on the basis that the defence of

\footnotetext{
${ }^{76}$ Commission Decision 2006/621/EC on the State Aid implemented by France for France Telecom [2006] OJ L257/11, Recitals 263 and 264.

${ }^{77}$ Commission v Germany (n 51), Opinion of AG Darmon, para 26.

${ }^{78}$ Fiat (n 4), Recital 356.
} 
legitimate expectations cannot be raised by a Member State and that there were no 'precise assurances. ${ }^{79}$ The argument of a 'novel' interpretation of EU State aid was raised by Luxembourg in the form of a breach of the principle of legal certainty. ${ }^{80}$ The Commission came down equally hard on this submission, but did make some noteworthy points.

Firstly, it argued that there were no past Commission decisions that might have created uncertainty about the fact that tax rulings can constitute measures of aid. ${ }^{81}$ This is uncontested. Secondly, it said that the 'Notice on Direct Business Taxation makes express reference to tax rulings and the circumstances according to which they could be considered to lead to the granting of State aid' ${ }^{82}$ The Notice makes the point that 'administrative rulings' may constitute incompatible aid, ${ }^{83}$ however, there is no reference to the arm's length principle or to the OECD for that matter. Thirdly, it rejected the idea that the 'novelty of the approach' should exclude recovery. The Commission argued as follows: ${ }^{84}$

\footnotetext{
'it has applied the arm's length principle in its past decision-making practice, in particular with respect to measures adopted by Luxembourg, and it concluded that a violation thereof could constitute State aid. ${ }^{85}$ That conclusion has further been confirmed by the Court of Justice. ${ }^{86}$ There is therefore nothing novel in the Commission's approach to the contested tax ruling. Member States should be aware that an agreement between a tax authority and a company that leads to a favourable treatment for the company in terms of artificially lowering its tax base, because the transfer prices it employs do not give a reliable approximation of a market-based outcome, lead to a violation of the State aid rules and should, in case of doubt, be notified to the Commission.'
}

This really appears to be the crux of the matter-whether the Commission's recent approach is novel. The Commission clearly will not budge from its position unless the CJEU rules against it following Fiat's appeal. ${ }^{87}$

\footnotetext{
79 ibid, Recitals 357 and 358. The Commission argued that the Code of Conduct Group was a non-binding agreement, and therefore, cannot be characterised as an assurance. It also argued that the OECD is not an EU institution and the EU is not a member of that organisation.

80 ibid, Recital 360.

81 ibid, Recital 361.

82 ibid. See Commission notice on the application of the State aid rules to measures relating to direct business taxation (98/C 384/03) (10.12.1998) OJ C 384/33, para 22: '[a]s far as administrative rulings merely contain an interpretation of general rules, they do not give rise to a presumption of aid'.

${ }^{83}$ Commission notice on the application of the State aid rules to measures relating to direct business taxation (n 82), para 22.

${ }^{84}$ Fiat (n 4), Recital 362. (Emphasis added).

${ }^{85}$ As cited by the Commission: "Commission Decision of 11 July 2001 in Case C 47/2001 (ex NN 42/2000) - Germany: Control and coordination centres of foreign companies, OJ 201 C 304, p. 2. Commission Decision 2003/501 of 16 October 2002 on the State aid scheme C 49/2001 (ex NN 46/2000) - Coordination Centres - implemented by Luxembourg, OJ 2003 L 170, p. 20".

${ }^{86}$ As cited by the Commission: "Joined Cases C-182/03 and C-217/03 Belgium and Forum 187 ASBL v. Commission ECLI:EU:C:2006:416".

${ }^{87}$ See Case T-755/15 Luxembourg v Commission (Action brought on 30 December 2015); Case T-759/15 Fiat Chrysler Finance Europe $v$ Commission (Action brought on 29 December 2015); Case T-760/15 Netherlands $v$ Commission (Action brought on 23 December 2015). In Fiat v Commission, the applicant argued that 'the contested decision breaches the principle of legitimate expectations since the Commission has created a legitimate expectation that for state aid purposes it assesses transfer pricing arrangements on the basis of the OECD Guidelines and its sudden departure from this has breached the principle of legitimate expectations'. Conversely, it must be noted that Luxembourg dropped its point on legitimate expectations in its appeal.
} 
There is no EU statute that makes the arm's length principle an EU-wide rule nor any case law, which confirms that the principle must be applied in all 28 Member States. The first instance where the Commission introduced the arm's length principle to determine economic advantage in transfer pricing cases were a result of the first wave of tax investigations in $2001^{88}$ and this was only vaguely confirmed by the CJEU in Forum $187 .^{89}$ The latter case confirmed that the Commission should use the cost-plus method recommended by the OECD apparently implying that a reference is to be made to the OECD Model Convention and Guidelines. As explained elsewhere ${ }^{90}$ there is a disparity between the arm's length principle applied in the OECD Guidelines and that applied by the Commission in its recent opening decisions. At face value, it seems that the Commission has departed from Forum 187 and applied the arm's length principle contrary to what multinationals would have legitimately expected.

\section{A. The Situation Before Forum 187}

Prior to Forum 187 there was no final decision of the Commission or the CJEU which employed the arm's length principle as a test to assess economic advantage. As already submitted, these decisions contain an incorrect application of this principle and moreover only a vague application thereof. Even if one were to take the Commission's and the CJEU's application of the arm's length principle in that case as correct (which is strongly contested), then the relevant point in time when all the beneficiaries in the internal market should have been aware of this distinct development in State aid law was in 2006 when the CJEU upheld the Commission's decision. Therefore, by way of example, in Apple there should be no order for recovery going further back than the date of the judgment in Forum 187 in 2006.

\section{B. The Situation After Forum 187}

There is a leap from the interpretation of State aid that the CJEU approved in Forum 187 (subject to the authors' reservations indicated above) and the Commission's recent interpretation. The premise here is slightly different. Multinationals were entitled to entertain legitimate expectations that the arm's length principle would be applied in line with Forum 187, and therefore, consistently with OECD Guidelines.

\footnotetext{
${ }^{88}$ Commission Decision 2003/438/EC (n 65), Recital 42; Commission Decision 2003/501/EC of 16 October 2002 on the State aid scheme for Coordination Centres implemented by Luxembourg [2003] OJ L 170/20, Recital 46. See also Commission Decision 2003/81/EC of 22 August 2002 on the aid scheme implemented by Spain in favour of coordination centres in Vizcaya [2003] OJ L31/26, Recitals 27 - 29; Commission Decision 2003/512/EC of 5 September 2002 on the aid scheme implemented by Germany for control and coordination centres [2003] OJ L177/17, Recitals 26 and 27; Commission Decision 2003/755/EC of 17 February 2003 on the aid scheme implemented by Belgium for coordination centres established in Belgium [2003] OJ L282/25, Recital 95; Commission Decision 2004/76/EC (n 68), Recitals 45-46; Commission Decision 2004/77/EC of 24 June 2003 on the aid scheme implemented by Belgium for tax ruling system for United States foreign sales corporations [2004] OJ L23/14, Recitals 60-62.

${ }^{89}$ Forum 187 (n 86), paras 94-96.

${ }^{90}$ Lovdahl Gormsen (n 6).
} 
The origin of the arm's length principle applied by the Commission to assess economic advantage can be found in the OECD Model Tax Convention and the accompanying OECD Guidelines. However, a degree of divergence can be observed between the interpretation of that principle by the OECD and how the Commission applied in the tax cases discussed here. Arguable, the Commission's interpretation and application of the arm's length principle in the first wave of tax investigations into national tax schemes in 2001 was superficial and manifested an air of exploration by the Commission. In fact, Forum 187 did not even mention the principle by its name. In the recent tax cases, the Commission has embarked on an aggressive application of this principle as if it were an exact science which produces a precise result on which economic advantage can be determined. This is clearly incorrect. The OECD Guidelines acknowledge that the choice of the methodology depends on a number of circumstances and note that each method will not generate a precise results, but likely an approximate range. More crucially, the Commission has imposed the arm's length principle, as interpreted by it, on all Member States despite the absence of harmonisation on transfer pricing assessment in the EU. Moreover, Forum 187 was a particularly extreme case, in which companies were essentially taxed on a completely notional basis. This is rather different to a case in which a tax authority genuinely tries to apply an arm's length standard.

The novelty is also clear in the discrepancies between the draft Commission Communication on the notion of aid in $2014^{91}$ and the final Commission Communication on the notion of aid in $2016 .{ }^{92}$ In the former, there was no express reference to the so-called arm's length principle or to the OECD Model Convention or its Guidelines for that matter. The draft Communication simply read that administrative tax ruling 'may' be used 'in determining arm's-length profits for related party transactions where the uncertainty may justify an advance ruling practice designed to ascertain whether certain controlled transactions are conducted at arm's length'. ${ }^{93}$ Then a reference was made to the Decision on the tax ruling system for US foreign sales corporations. ${ }^{94}$ In a subsequent paragraph, the Commission was more expressive when it said: ${ }^{95}$

As a result, tax rulings should only aim to provide legal certainty to the fiscal treatment of certain transactions and should not have the effect of granting the undertakings concerned lower taxation than other undertakings in a similar legal and factual situation (but which were not granted such rulings). As demonstrated by the Commission's decisional practice, rulings allowing taxpayers to use alternative

\footnotetext{
${ }^{91}$ Commission, 'Draft Commission Notice on the notion of State aid pursuant to Article 107(1) TFEU' (2014).

${ }^{92}$ Commission, 'Commission Notice on the notion of State aid as referred to in Article 107(1) TFEU' [2016] OJ C262/1.

${ }^{93}$ Draft Commission Notice (n 91), Recital 174.

${ }^{94}$ Commission Decision 2004/77/EC of 24 June 2003 on the aid scheme implemented by Belgium for tax ruling system for United States foreign sales corporations [2004] OJ L23/14, Recital 761.

${ }^{95}$ Draft Commission Notice (n 91), Recital 176.
} 
methods for calculating taxable profits, e.g. the use of fixed margins for a cost-plus or resale-minus method for determining an appropriate transfer pricing, may involve State aid.

Again there is no clear mentioning of either an overarching arm's length principle or the OECD Model Convention or its Guidelines. Indeed this Recital 176 ends with a footnote ${ }^{96}$ referring to a number of Commission decisions following the so-called first wave of investigations into tax schemes in 2001, including Forum 187. This is a stark contrast from the amendments to the final Communication which is very expressive and emphatic as to the arm's length principle and enters into great detail on how State aid analysis is to be conducted in cross-border transfer pricing arrangements, irrespective of a tax ruling. ${ }^{97}$ This was also followed by the DG Competition's internal working paper on State aid and tax rulings as a background note to the High Level Forum on State Aid of 3 June 2016 which was also very expressive. ${ }^{98}$

The authors question how the Commission can be so adamant that there is 'nothing novel' in its approach vis-à-vis the arm's length principle if it felt the need following the initial opening decision in Amazon and the final decisions in Starbucks, Fiat and Apple to elaborate in such detail on its approach.

\section{Beyond Forum 187: Selectivity}

The extract cited above from the non-confidential decision published in Fiat, clearly shows that the Commission fails to appreciate the inherently different nature of multinational companies as against SMEs, purely national structure or shell companies. Even though that specific extract does not take into account the issue of 'selectivity' per se, it is clear from the Commission's approach that it is pushing for a wider interpretation of this criterion which fails to take into account the nuances and peculiarities of beneficiaries. This approach has been challenged in the past ${ }^{99}$ and it is still being challenged by beneficiaries in other recent tax related cases, ${ }^{100}$ therefore, implying that it is not an established rule of interpretation of State aid law. The Commission, on this point, cannot seriously replicate the same

\footnotetext{
${ }^{96}$ See Commission Decision 2003/438/EC (n 65), Recitals 43 and 44; Commission Decision 2003/501/EC (n 65), Recitals 46-47 and 50; Commission Decision 2003/755/EC of 17 February 2003 on the aid scheme implemented by Belgium for coordination centres established in Belgium [2003] OJ L282/55, Recitals 89 to 95 and the related Joined Cases C-182/03 and C-217/03 Forum 187 ECLI:EU:C:2006:416, paras 96 and 97; Commission Decision 2004/76/EC (n 68), Recitals 50 and 53. ${ }^{97}$ Commission Notice on the notion of State aid (n 92), Recitals 169-174.

${ }^{98}$ See DG Competition Working Paper on State Aid and Tax Rulings, dated 3 June 2016 available at http://ec.europa.eu/competition/state_aid/legislation/working_paper_tax_rulings.pdf.

99 World Duty Free (n 8). By way of an example see also, Commission Decision of 29 July 2016 on State aid SA.42007 Belgium - Alternative income tax regime for the wholesale diamond sector, Recitals 44-49.

${ }^{100}$ Commission Decision of 4 July 2016 on State aid SA.79769 implemented by Spain for certain football clubs, has been challenged by a number of beneficiaries. See: T-679/16 Athletic Club v Commission; T-845/16 QG v Commission; T-846/16 QF v Commission; T-865/16 Futbol Club Barcelona v Commission.
} 
argument it has put forward on the interpretation of the arm's length principle. As explained elsewhere, ${ }^{101}$ the jurisprudence since Gibraltar is inconsistent, ${ }^{102}$ and therefore, the Commission may not (as it did in Fiat) rely on 'precedent' to argue that operators like Starbucks, Fiat and Apple and any other undertakings should be treated like for like.

There are some parallels to be drawn from the seminal Leipzig/Halle Airport case where the appellants argued that the Commission could not rely on a widened interpretation of 'undertaking' and 'economic activity' to order recovery. ${ }^{103}$ The CJEU rejected this argument and referred back to the earlier case of Aeroports de Paris which widened that definition to justify the Commission's reliance on precedent. ${ }^{104}$ The CJEU, therefore, held that the principle of non-retroactivity was observed. Two comments should be made on this judgment. Firstly, Aeroports de Paris was a clear judgment, unlike Forum 187 or the strand of jurisprudence following Gibraltar, and therefore, a beneficiary would have been expected to be on 'notice' of the shift in interpretation of 'undertaking'. Secondly, this novel interpretation of State aid law was allowed by the CJEU only to apply after 14 December 2000 - the date of the judgment in Aeroports de Paris. This approach is in stark contrast with that adopted by the Commission in the present tax cases where not only does it not have in hand a clear pronouncement on the interpretation of the arm's length principle and the selectivity criterion, but also it is applying a novel interpretation advanced by none other than itself retroactively.

\section{The Principles of Legal Certainty and Proportionality in Recovering State aid}

The principle of legitimate expectations is an inextricable part of legal certainty. This is clear from the fact that case law of the CJEU barely distinguishes the two. ${ }^{105}$ In the realm of EU State aid law, it is accepted that recovery should not be ordered, if that would be contrary to the principle of protection of legitimate expectations. However, the defence of legitimate expectations has been construed narrowly. ${ }^{106}$ The CJEU's view is that the beneficiary can rely on this principle to oppose the recovery of unlawful aid in exceptional circumstances.

That said, apart from the protection of legitimate expectations, the principle of legal certainty manifests itself in other key rules of EU administrative law. Firstly, in limitation periods which require that

\footnotetext{
${ }^{101}$ Lovdahl Gormsen (n 6).

${ }_{102}$ Cases C-106/09 P and C-107/09 P Commission v Government of Gibraltar and United Kingdom ECLI:EU:C:2011:732.

${ }^{103}$ Case C-288/11 P Mitteldeutsche Flughafen AG and others v Commission ECLI:EU:C:2012:821.

${ }^{104}$ Case T-128/98 Aeroports de Paris v Commission ECLI:EU:T:2000:290.

${ }^{105}$ A recent example within the context of EU State aid is Case C-89/14 A2A SpA ECLI:EU:C:2015:537.

${ }^{106}$ See Commission v Germany (n 65); Case C-199/06 CELF ECLI:EU:C:2008:79 [2008] ECR I-0469 ('CELF I judgment'), paras 66-68 and Case C-1/09 CELF ECLI:EU:C:2010:136 [2010] ECR I-2099, para 45.
} 
recovery of aid is limited to what the beneficiary received for the past 10 years. Secondly, in the idea that rules, including State aid rules, should be clear and precise ${ }^{107}$ - also in their application - and that such rules should never apply retroactively. Even if one traces the very origin of the principle of legitimate expectations, it was said that: ${ }^{108}$

'this principle cannot be extended to the point of generally preventing new rules from applying to the future effects of situations which arose under the earlier rules in the absence of obligations entered into with the public authorities.'

This makes sense. The principle of legitimate expectations cannot be applied to block future legislation or even administrative work by EU institutions, so long as the effects are not retroactive. This precisely encapsulates the tension between a beneficiary's right to reasonable legitimate expectations and the inherent retroactive character of an order for recovery. EU institutions have the onus to perform their duties in a manner which is predictable - lest this statement is misinterpreted, there should always be scope for an interpretation and application of the law which is in constant adaptation to the realities around us, but not to the detriment of individuals or economic operators based in the EU.

However, the application of a novel interpretation and application of State aid, as any other aspect of EU law, should always be forward looking, ${ }^{109}$ even in the absence of a precise assurance. As mentioned, when assessing the existence of legitimate expectations, the relevant standard is that of a diligent businessman'. ${ }^{110}$ Thus, the CJEU has repeatedly held that a diligent businessman could normally determine whether the procedure set out in Article 108(3) TFEU has been followed when granting an aid, and therefore whether the recipient of the aid can entertain legitimate expectations in a particular case. Nevertheless, one can imagine that in some cases, an undertaking could not safely determine whether a measure constitutes notifiable aid within the meaning of Article 107(1) TFEU. This is not merely a theoretical possibility, as the courts in the past have examined a number of cases, wherein the presence of State aid was far from evident. ${ }^{111}$ In his Opinion in SFEI and Others, AG Jacobs held that ordering the recovery of the aid would be inappropriate, since a diligent businessman would not be able to determine whether the procedure set out in Article 108(3) TFEU has been respected. His reasoning thereto was enlightening: ${ }^{12}$

\footnotetext{
${ }^{107}$ See Case C-110/03 Belgium v Commission ECLI:EU:C:2005:223, see first limb of the first plea. ${ }^{108}$ Case 84/78 Ditta Angelo Tomadini Snc ECLI:EU:C:1979:129, para 21; Case C-112/80 Dürbeck ECLI:EU:C:1981:94, para 48; Also see Case C-596/13 P Commission v Moravia Gas Storage, para 46 and the case law cited therein. ${ }^{109}$ Eleanor Sharpston, 'European Community Law and the Doctrine of Legitimate Expectations: How Legitimate, and for Whom' (1990) 11(1) Northwestern Journal of International Law \& Business 87, 93 also noted that legitimate expectations may also arise when the measure is forward looking.

110 See Commission v Germany (n 65); Joined cases C-346/03 and C-529/03 Atzeni and Others ECLI:EU:C:2006:130 [2006] ECR I-1875, para 64.25); Joined cases C-346/03 and C-529/03 Atzeni and Others ECLI:EU:C:2006:130 [2006] ECR I-1875, para 64 .

${ }^{111}$ Quigley (n 57) 585.

${ }^{112}$ Case C-39/94 ECLI:EU:C:1995:445 [1996] ECR I-3547, Opinion of AG Jacobs, para 76 (emphasis added).
} 
'In the present case it seems doubtful [whether a diligent businessman ought to have realized that the measures in question constituted aid] [...] the measures in question are not ones which self-evidently constitute aid [...] [i]n such circumstances the national court, if it were to find that the measures constitute aid, may in my view be justified in considering it inappropriate to order repayment of the aid'.

The interpretation advocated by this paper is grounded on firm theoretical grounds and duly respects the normative aspirations of legal certainty. Thus, our position does not derive from a purist approach to State aid law, which criticises the Commission's approach solely on the basis that it strategically utilises its powers under State aid control to achieve policy objectives in the field of taxation. The opposite interpretation would be a source of legal uncertainty, which can chill trade activity. It would be wrong for any EU institution, let alone the Commission, to expect any investor to submit to any change in law or policy if it wants to operate in the internal market. This highlights the importance of legal certainty in the realm of private economic activity. The latter depends on advance planning which allows the development of business and reduces transaction costs. ${ }^{113}$ The Venice Commission acknowledges this important aspect of legal certainty and describes the latter as an essential element of productive business arrangements which can generate growth. ${ }^{114}$ Legal certainty, as an integral element of the rule of law, can reduce business risks and function in the interests of increased investment. ${ }^{115}$ In that context, the general prohibition of retroactivity, seeks to protect private economic transactions by safeguarding the grounds upon which business decisions were made. ${ }^{116}$ The preceding remarks are particularly relevant for the assessment of APAs with multinational enterprises. Taxation is a complex legal area and its inherent uncertainty can chill desired economic activity. Therefore tax rulings can often produce a more certain and thus better taxation environment. ${ }^{117}$ The CJEU has also stressed that the principle of legal certainty is all the more prominent, when the measure at issue is capable of having financial consequences. ${ }^{118}$

The effect of such uncertainty can be twofold. Firstly, legal uncertainty is perceived as a general obstacle to market activity. Market transactions are facilitated by the ease of rational decision-making for which uncertainty is an aggravating factor. ${ }^{119}$ Secondly, an environment of legal uncertainty increases transaction costs for each transaction performed or economic move made. ${ }^{120}$ Ambiguity does

\footnotetext{
113 Tridimas (n 25) 242.

114 Venice Commission (n 24), para 44.

${ }^{115}$ Robert McCorquodale, 'Business, the International Rule of Law and Human Rights' in Robert McCorquodale (ed), The Rule of Law in International \& Comparative Context (BIICL 2010) 46.

${ }^{116}$ Craig (n 35) 550.

117 Lovdahl Gormsen (n 6) 371.

${ }^{118}$ Emsland-Stärke (n 27).

${ }^{119}$ Iain MacNeil, 'Uncertainty in Commercial Law' (2009) 13(1) Edinburgh Law Review 68, 71 et seq.

120 ibid 72.
} 
not only lead to increased consultancy costs in advance of an economic behaviour but may also result in costly litigation.

The general prohibition against the retroactive application of legal norms, can only be circumvented when the conditions established in Racke are fulfilled:121

'Although in general the principle of legal certainty precludes a Community measure from taking effect from a point in time before its publication, it may exceptionally be otherwise where the purpose to be achieved so demands and where the legitimate expectations of those concerned are duly respected.'

The CJEU further elaborated that 'exceptionally' means overriding considerations. ${ }^{122}$ Although the definition is slightly circular, with a double reference to general principles of EU law, it is the test applied today to establish whether a measure is to have retroactive effect. The wording indicates that retroactivity can only be implemented in constrained cases where there is a compelling object of EU law. ${ }^{123}$ The reference to the legitimate expectations of individuals can rightly be understood as a test of proportionality. ${ }^{124}$ Only where there is no significant individual interest may a public interest of retroactivity prevail. Thus, the Commission should have applied the Racke test before engaging in a novel interpretation of State aid law to the detriment to a beneficiary's already established legal and economic situation. The Commission's failure to apply this test makes the order for recovery in breach of the principles of legal certainty and protection of legitimate expectations.

Another dimension worth considering concerns the proportionality of the recovery orders in the recent tax cases. As case law stands, arguing that a recovery order is disproportionate is a defence unlikely to bear fruit. ${ }^{125}$ This is a logical consequence of the position expressed in case law that the recovery of aid does not constitute a penalty. ${ }^{126}$ However, it is submitted that this stance vis-à-vis the proportionality argument might need to be reconsidered in these specific cases. The remedy imposed in Apple is excessive, especially when considering that it is based on a novel interpretation of State aid law. If the Commission had decided to use its enforcement powers to develop the notion of State aid further, it could have done so gradually, through a trial and error approach reviewed by the CJEU, and in any case would be applied ex nunc. This gradual approach would be attuned to the need to clarify the legal concepts and apply State aid law in a coherent manner, whilst drawing from the enforcement experience

\footnotetext{
${ }^{121}$ Case C-98/78 Racke ECLI:EU:C:1979:14, para 20. See also Case 99/78 Decker v Hauptzollamt Landau ECLI:EU:C:1979:15 [1979] ECR 0101, para 8; Joined Cases 212 to 217/80 Meridionale Industria Salumi and Others ECLI:EU:C:1981:270 [1981] ECR 2735, para 10; Case 224/82 Meiko ECLI:EU:C:1983:219 [1983] ECR 2539, para 12; Case C-459/02 Gerekens and Procola ECLI:EU:C:2004:454 [2004] ECR I-7315, para 23.

122 Racke (n 121), para 20.

${ }^{123}$ Craig (n 35) 551.

${ }^{124}$ Schmahl (n 30) 300.

${ }^{125}$ Quigley (n 57) 586.

126 ibid.
} 
of a growing body of decisions. Alternatively, the Commission could have acknowledged that State aid law is not a cure for all maladies and therefore not an appropriate policy response to the particular problems at issue, namely the challenges of base erosion and profit shifting (BEPS). The latter could be tackled through other means, such as reinforcing multilateral co-operation in the context of OECD, or even introducing legislative measures.

The 2011 proposal for a common consolidated corporate tax base (CCCTB), ${ }^{127}$ which provided that groups of companies would be subject to harmonised tax rules across the EU and face only one tax authority ('one-stop-shop'), was perhaps too ambitious, and its adoption was postponed until the 'Greek calends'. In October 2016, the Commission decided to re-launch this initiative. ${ }^{128}$ Contrary to the 2011 proposal, which envisaged that the harmonization would be achieved in a single-step approach, the 2016 proposal endorses a gradual approach, whereby Member States will agree on a common base first and will address the more difficult aspects (consolidation) at a later stage. It remains to be seen if this proposal will have better luck than its predecessor. In the meantime, the EU has adopted an anti-tax avoidance directive, ${ }^{129}$ which implements many of the BEPS reforms and comes into effect on 1 January 2019.

In any case, the fact that the route of legislative harmonisation of the proposed CCCTB rules faces insurmountable political obstacles is no excuse for the Commission to resort to a wide interpretation and application of Articles 107 and 108 TFEU to circumvent the legislative arena. Despite the difficulties, the Commission should not renounce the quest of trying to strike an agreement with all the stakeholders in the legislative process. What is more, legislation has another advantage vis-à-vis the State aid route, as the latter can only be an effective policy tool insofar as a national measure falls within the notion of aid pursuant to Article 107(1) TFEU. This, however, might not always be the case. To insist on this strategy, the Commission risks undermining the clarity of the law by excessively widening the concept of aid, rendering it a catch-all term. This criticism is not unfounded, as the Commission, until now, has disregarded the alternative routes. Instead, it has argued that the recent tax cases reflect the jurisprudence as it always stood. This is clearly an inaccurate assertion.

\footnotetext{
${ }^{127}$ Commission, 'Proposal for a Council Directive on a Common Consolidated Corporate Tax Base (CCCTB)' (3.10.2011) $\operatorname{COM}(2011) 121$ final/2; European Parliament, 'Tax policy in the EU: Issues and challenges' (February 2015) 25 http://www.europarl.europa.eu/RegData/etudes/IDAN/2015/549001/EPRS_IDA(2015)549001_EN.pdf. ${ }^{128}$ See Commission, 'Common Consolidated Corporate Tax Base (CCCTB)', https://ec.europa.eu/taxation_customs/business/company-tax/common-consolidated-corporate-tax-base-ccctb_en. ${ }^{129}$ Council Directive (EU) 2016/1164 of 12 July 2016 laying down rules against tax avoidance practices that directly affect the functioning of the internal market.
} 
Commissioner Vestager was quoted to have said that 'if you want legal certainty you need a Commission decision that creates legal certainty'. ${ }^{130}$ This extremely circular statement shows a lack of appreciation towards the general principles of EU law, both legal certainty and legitimate expectations. As highlighted above, the authors are not contesting that the Commission should not push for an expansive interpretation and application of the law, ${ }^{131}$ but rather contesting that there should not have been an order of recovery in its decisions against Starbucks, Fiat and Apple - whatever the amount of aid to be recovered.

\section{Conclusion}

This article questions the Commission's order of recovery in the recent tax cases, which is highly questionable. Not only because of the Commission's distinct development of State aid law, but also due to the way in which it selected to impose an enormous recovery obligation on selective number of multinational groups. The Commission's distinct development runs counter to the general principle of EU law of legal certainty and breaches the legitimate expectations of multinational companies.

If the Commission was really concerned with tackling harmful tax competition - a valuable public concern - it could have engaged with the relevant Member States in question, their tax and accounting bodies and multinational groups affected by the Commission's change in its State aid analysis. Such engagement would have created a proper basis for determining the circumstances in which State aid enforcement might apply to tax rulings and, in particular, the basis and extent to which an arm's length principle could be utilised. This could have led to the adoption of guidelines or updated its 1998 Notice on direct tax or to amend the Code of Conduct. However, no such steps were taken by the Commission prior to launching the investigations.

The Commission could also have proposed to the Council a new regulation on the basis of Article 109 TFEU, which provides specifically EU legislation defining the application of Articles 107 and 108 TFEU respectively. Given the repercussions of the Commission's distinct development in State aid analysis, it would have been entirely appropriate to have adopted such a regulation, which could have been stated to apply prospectively.

\footnotetext{
${ }^{130}$ Quoted in the Financial Times 1 September 2016 'Washington will not let Brussels have the last word on Apple' by Itai Grinberg' available at https://www.ft.com/content/11e2e94c-702d-11e6-a0c9-1365ce54b926.

${ }^{131}$ See Lovdahl Gormsen (n 6) for a specific critique of this.
} 
We now know that the Commission decided not to propound its distinct development in State aid analysis in advance so as to afford those affected the opportunity to amend their arrangements with national tax authorities. This would have achieved the Commission's task of ensuring the proper application of State aid law as to the future whilst not imposing an enormous recovery obligations on a small and selective number of companies that the Commission has chosen to investigate. ${ }^{132}$ It is hard not to come to the conclusion that this is disproportionate.

${ }^{132}$ Liza Lovdahl Gormsen, 'By singling out Apple over taxes, Brussels is abusing its own rules' http://www.telegraph.co.uk/business/2016/08/28/brussels-mustnt-achieve-tax-reform-by-using-state-aid-rules-crea/ The Telegraph 29 August 2016. 